\title{
An Unusual Dermoid Cyst of the Pineal Region: Case report in a Child
}

\section{Cisto dermóide incomum da região da pineal: Relato de} caso em uma criança

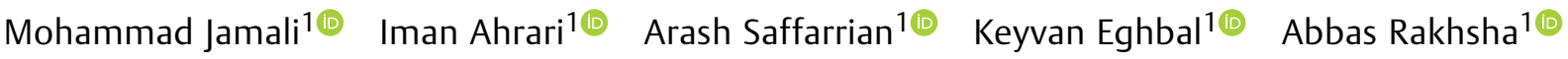 \\ Sulmaz Ghahramani ${ }^{2}$ \\ ${ }^{1}$ Department of Neurosurgery, Shiraz University of Medical Sciences, \\ Shiraz, Iran \\ ${ }^{2}$ Health Policy Research Center, Institute of Health, Shiraz University \\ of Medical Sciences, Shiraz, Iran \\ Address for correspondence Sulmaz Ghahramani, MD, Shiraz \\ University of Medical Sciences, Shiraz, Iran (e-mail: suli. \\ ghahraman@gmail.com).
}

Arq Bras Neurocir 2021;40(1):97-100.

\section{Abstract \\ Keywords \\ - dermoid cyst \\ - pineal tumor \\ - hydrocephalus \\ - hairy structure}

\section{Resumo}

\section{Palavras-chave}

- cisto dermoide

- tumores da região pineal

- hidrocefalia

- estrutura cabeluda
Introduction The pineal gland is a common location for intracranial germ cells, but dermoids are not commonly observed in this area. In the present paper, we discuss the clinical and radiological features as well as the treatment and outcome of this cyst in a 6-year- old child with a pineal dermoid cyst.

Case Presentation The patient presented with chronic headache 6 months before admission in 2018. On the first admission, an enhanced lesion with a small cyst was detected in brain imaging. Magnetic resonance imaging (MRI) of the brain at follow-up (2 months after the first presentation) showed enlargement of the cyst size with compression on the adjacent structures. Radical excision of the tumor was performed after the endoscopic biopsy due to pressure exerted on the adjacent structures. Conclusion Dermoid cyst should be considered as a differential diagnosis for enhanced lesions of the pineal region.

Introdução A glândula pineal é uma localização comum para as células germinativas intracranianos, mas dermoids não são frequentemente observados nesta área. No presente artigo, discutimos as características clínicas e radiológicas, bem como o tratamento e a evolução desse cisto em uma criança de 6 anos com cisto dermóide pineal.

Apresentação do caso $O$ paciente apresentou cefaleia crônica 6 meses antes da admissão em 2018. Na primeira admissão, uma lesão acentuada com um pequeno cisto foi detectada na imagem do cérebro. A ressonância magnética (RM) do cérebro no seguimento ( 2 meses após a primeira apresentação) mostrou aumento do tamanho do cisto com compressão das estruturas adjacentes. A excisão radical do tumor foi realizada após a biópsia endoscópica devido à pressão exercida nas estruturas adjacentes.

Conclusão O cisto dermóide deve ser considerado um diagnóstico diferencial para lesões acentuadas da região pineal. received

July 21,2020

accepted

September 4, 2020

published online

November 26, 2020
DOI https://doi.org/ 10.1055/s-0040-1719006. ISSN 0103-5355.

\footnotetext{
(c) 2020. Sociedade Brasileira de Neurocirurgia. All rights reserved. This is an open access article published by Thieme under the terms of the Creative Commons Attribution-NonDerivative-NonCommercial-License, permitting copying and reproduction so long as the original work is given appropriate credit. Contents may not be used for commercial purposes, or adapted, remixed, transformed or built upon. (https://creativecommons.org/ licenses/by-nc-nd/4.0/)

Thieme Revinter Publicações Ltda., Rua do Matoso 170, Rio de Janeiro, RJ, CEP 20270-135, Brazil
} 


\section{Introduction}

Dermoid cysts (benign congenital cysts) account for $0.1 \%$ to $0.7 \%$ of embryonal malformations, and arise from defects in the separation of the neuroectoderm during the neural tube formation. This leads to sequestration of ectodermal remnants. ${ }^{1,2}$ It can arise in the posterior fossa, mostly in the midline position in the vermis, in nearby meninges or in the cavity of the $4^{\text {th }}$ ventricle. ${ }^{3-6}$ Although the pineal gland is a common location for intracranial germ cells and epidermoids ( 40-50\%), dermoids are not commonly observed in this area. ${ }^{7,8}$

Patients with dermoid cysts are usually asymptomatic, although they may present symptoms related to local mass effect, seizures, or recurrent meningitis. ${ }^{9}$ On computed tomography (CT) scans, dermoid cysts usually appear as rounded, well-circumscribed, non-enhancing, hypodense lesions. Moreover, on magnetic resonance images (MRI), they demonstrate increased T1- and variable T2-weighted signal. ${ }^{10,11}$

In the present paper, we discuss the clinical and radiological features, as well as the treatment and outcome of this cyst in a 6-year old child with a pineal dermoid cyst.

\section{Case Presentation}

The patient was a 6 -year-old boy who presented with chronic headache 6 months before admission in 2018. His past medical and family histories were unremarkable for any childhood illnesses, malignancies or fetomaternal complications. Moreover, no documented developmental delays were observed in the patient and papilledema was found in his neurological examination. In addition, routine laboratory tests and markers of germ cell tumors were checked, and all were within normal limits.

Imaging. Brain MRI was performed with and without intravenous Gadolinium Contrast Medium (Gd), showing a well-defined extra axial $1 \times 2 \mathrm{~cm}$ T1W hypointense, T2W hyperintense solid-cystic lesion and enhancement with contrast; the midline in the.cystic component of the pineal region was very small. Moreover, no significant pressure was observed on the adjacent structures ( - Fig. $\mathbf{1}$ ).

Operation and Outpatient follow-up. In the first admission, the patient presented with drowsiness and headache. Due to the presence of hydrocephalus and nonprepared endoscopic setting at the admission time, a ventriculoperitoneal (VP) shunt was inserted. In the same admission, a brain MRI was performed. Assessment of tumor markers including Beta-Human Chorionic Gonadotropin ( $\beta-\mathrm{HCG}$ ) and Alpha Fetoprotein (AFP) was negative for germ cell tumor. Due to the improvement of his condition, the patient was discharged. Two months after the first presentation, the patient developed ataxia and upgaze palsy. A subsequent brain MRI revealed enlargement of the cystic lesion behind the solid mass with compressive effects on the adjacent structures and unilateral hydrocephalus.

An endoscopic transventricular approach was performed for biopsy. The endoscopic view revealed hair-like structures on both the outer surface of the cyst and the in solid lesion, in favor of a dermoid cyst (-Fig. 2). Histopathologic studies confirmed the diagnosis of dermoid cyst. A brain MRI showed enlargement of the cyst size with compression on the adjacent structures. Open surgery was performed using the infratentorial-supracerebellar approach for total resection of the lesion (-Fig. 2).

Histopathology: The histopathologic study of the specimens from both the first and second operations was in favor of the dermoid cyst (-Fig. 3 ).

Hospital course: Postoperatively, the neurological status of the patient was stable, but the upgaze palsy persisted. Follow-up: after 2 months, the patient was visited and showed reduced upgaze palsy. Moreover, he demonstrated no signs and symptoms of high intracranial pressure.

\section{Discussion}

The present study aimed to present a 6-year-old boy with a dermoid cyst of the pineal region. However, it is evident that epidermoid and dermoid cysts are well-differentiated benign cysts that may be rarely observed in the pineal region. Considering the inaccessibility of the pineal region, distinguishing benign, surgically resectable tumors such as teratomas as well as epidermoid and dermoid cysts from malignant ones is of utmost importance. ${ }^{12}$

The patient presented with headache, although most of the intracranial dermoid cysts are asymptomatic and are usually found incidentally. The clinical presentation is limited to vague symptoms, such as headache. Mass effects or rupture of the cyst may cause sudden clinical findings. ${ }^{2,9}$

The advent of CT scans and, more recently, of MRI, has facilitated the diagnosis of pineal-origin lesions. On CT scanning, dermoid cysts are shown as low-density lobulated masses with correspondent peripheral calcifications. Hyperdensity might rarely be demonstrated, due to a combination of saponification, microcalcification, and blood products. Although dermoid cysts may show variable signal characteristics on MRI in T1, they are typically hyperintense due to cholesterol components and usually do not enhance with Gd. However, extensive pial contrast enhancement may be present in chemical meningitis caused by ruptured cysts. On T2, various signals ranging from hypo- to hyperintense may be observed. ${ }^{10,13}$ The brain MRI in this case is mystifying. In T1weighted images, the mass is hypointense with enhancement of Gd.

The key point for surgical treatment of cysts is their radical excision. However, it is a challenging approach because it requires localization. In a reported series of epidermoid cysts, in some cases, the surgeon preferred to intentionally leave in situ fragments of the adherent capsule to the deep veins of this region to avoid any risk. ${ }^{14,15}$ Operation approaches are more studied on epidermoid cysts than in dermoid cysts, considering their higher prevalence. ${ }^{14}$

The prognosis of patients with dermoid cysts appears appropriate after resection. ${ }^{9}$ In this case, the 4 - and 8 -month outcome after total resection is favorable. 

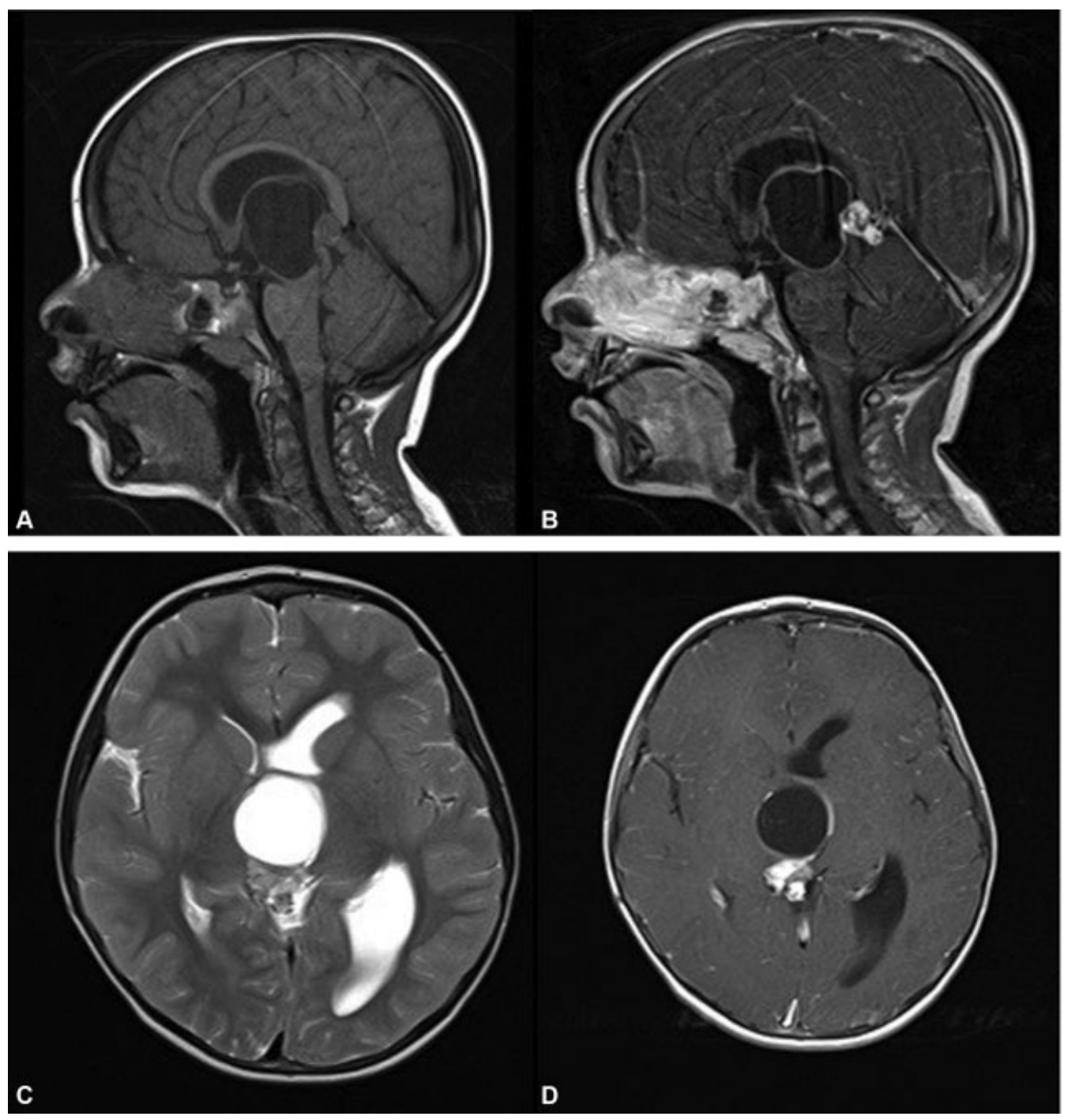

Fig. 1 Sequences of the lesion on performing magnetic resonance imaging showing low signal intensity on T1-weighted images (A) and heterogeneously high signal intensity on T2-weighted images (B) and enhancement after injection of intravenous contrast (C, D).

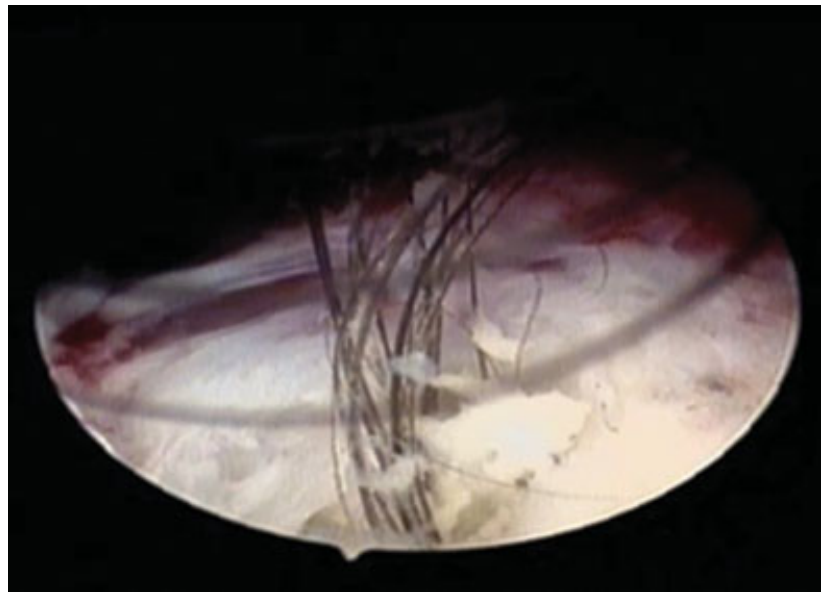

Fig. 2 Intraoperative gross appearance of cystic lesion with hair tissue.

In the present study, a case was presented with a pineal lesion surrounded by a huge cyst. Brain MRI of the case was not typical. A previous presentation of a dermoid cyst was reported in the posterior fossa, suprasellar and auricular areas. ${ }^{9}$ However, emergence of a dermoid cyst in the pineal region is unusual, but it is always on a differential that a tumor of the pineal region may be a epidermoid or dermoid. ${ }^{16}$ For the case, emergency VP shunting was performed due to hydrocephalus, and the endoscopic approach was used to drain the cyst and take biopsies from the lesion. Moreover, the total resection method was selected for the case due to the pressure effect of the lesion on the surrounding structures. The cyst was totally excised with no damage to the adjacent structures.

\section{Conclusion}

We reported an unusual case with a dermoid cyst in the pineal region. Radical removal of the cyst was performed after the endoscopic biopsy due to pressure exerted on the adjacent structures. The risk of injury to the cerebellar hemisphere and other structures should be considered. 


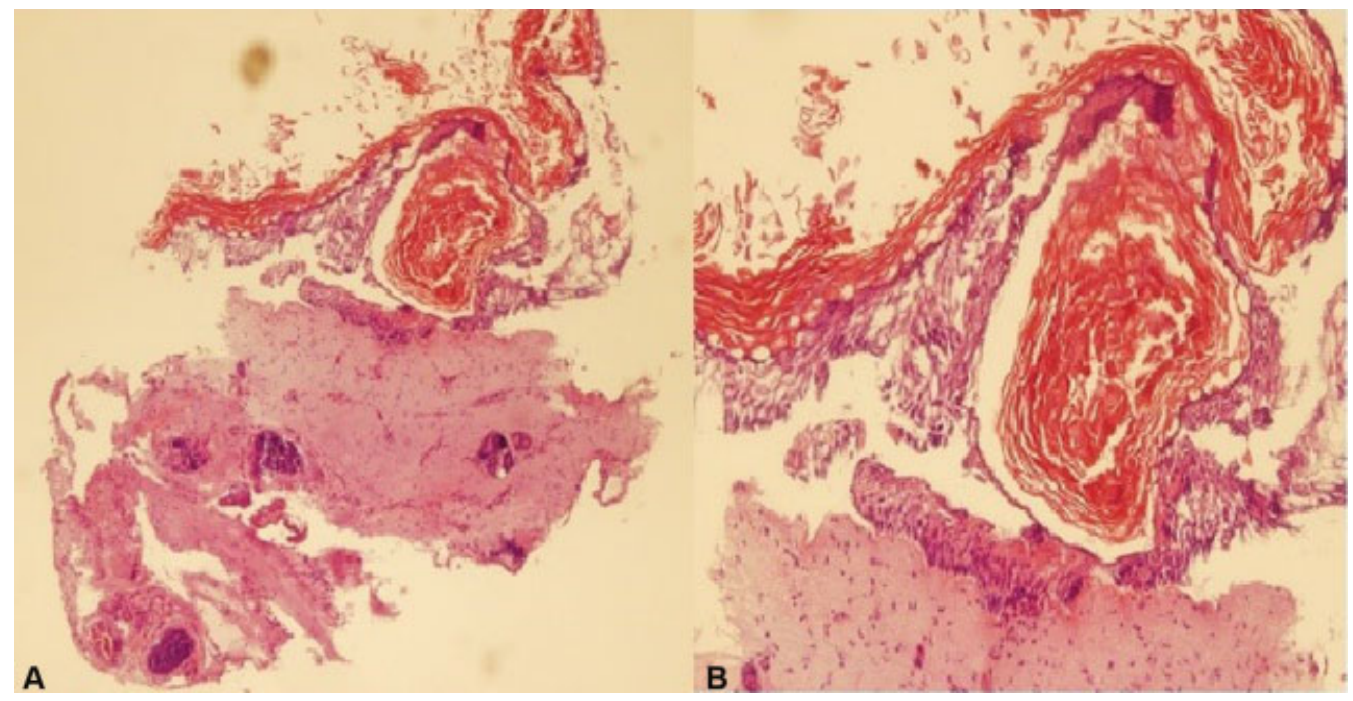

Fig. 3 (A) Cystic lesion with a fibrous wall partially lined by stratified epithelium and keratinized components that is consistent with the diagnosis of a dermoid cyst. (B) Higher magnification of the area shown in (A).

Therefore, we suggest stereotaxic or endoscopic approaches in the case of small lesions.

\section{Conflict of Interests}

The authors have no conflict of interests to declare.

\section{References}

1 Guidetti B, Gagliardi FM. Epidermoid and dermoid cysts. Clinical evaluation and late surgical results. J Neurosurg 1977;47(01): $12-18$

2 Smirniotopoulos JG, Chiechi MV. Teratomas, dermoids, and epidermoids of the head and neck. Radiographics 1995;15(06): 1437-1455

3 Groen RJ, van Ouwerkerk WJ. Cerebellar dermoid tumor and occipital meningocele in a monozygotic twin: clues to the embryogenesis of craniospinal dysraphism. Childs Nerv Syst 1995;11 (07):414-417

4 Higashi S, Takinami K, Yamashita J. Occipital dermal sinus associated with dermoid cyst in the fourth ventricle. AJNR Am J Neuroradiol 1995;16(04):945-948

5 Logue V, Till K. Posterior fossa dermoid cysts with special reference to intracranial infection. J Neurol Neurosurg Psychiatry 1952;15(01):1-12

6 Akhaddar A, Jiddane M, Chakir N, El Hassani R, Moustarchid B, Bellakhdar F. Cerebellar abscesses secondary to occipital dermoid cyst with dermal sinus: case report. Surg Neurol 2002;58(34):266-270
7 Jennings MT, Gelman R, Hochberg F. Intracranial germ-cell tumors: natural history and pathogenesis. J Neurosurg 1985;63 (02):155-167

8 Baykaner MK, Ergun E, Cemil B, Bayik P, Emmez H. A mature cystic teratoma in pineal region mimicking parietal encephalocele in a newborn. Childs Nerv Syst 2007;23(05):573-576

9 Kahilogullari G, Yakar F, Bayatli E, Erden E, Meco C, Unlu A. Endoscopic removal of a suprasellar dermoid cyst in a pediatric patient: a case report and review of the literature. Childs Nerv Syst 2018;34(08):1583-1587

10 Brown JY, Morokoff AP, Mitchell PJ, Gonzales MF. Unusual imaging appearance of an intracranial dermoid cyst. AJNR Am J Neuroradiol 2001;22(10):1970-1972

11 Sanchez-Mejia RO, Limbo M, Tihan T, Galvez MG, Woodward MV, Gupta N. Intracranial dermoid cyst mimicking haemorrhage. J Neurosurg 2006;105(04):311

12 Shah A, Sadasivan B, Leng BM, Ho J. A teratocarcinoma developing after gross total excision of a pineal teratoma in a patient with systemic lupus erythematosus. Neurol Res 1995;17(03):229-232

13 Osborn AG, Preece MT. Intracranial cysts: radiologic-pathologic correlation and imaging approach. Radiology 2006;239(03):650-664

14 Hassani FD, Bouchaouch A, El Fatemi N, Gana R, El Abbadi N, Maaqili MR. Pineal epidermoid cyst: case report and review of the literature. Pan Afr Med J 2014;18(01):259

15 Konovalov AN, Spallone A, Pitzkhelauri DI. Pineal epidermoid cysts: diagnosis and management. J Neurosurg 1999;91(03): 370-374

16 Hudgins RJ, Hudgins PA. Pineal Region Tumors in Children. Contemp Neurosurg 1990;12(22):1 